\title{
DURABILITY ASSESSMENT OF WESTERN JUNIPER FROM FIVE DIFFERENT GROWING REGIONS
}

\author{
Byrne T. Miyamoto $\dagger$
}

Graduate Research Assistant

E-mail: byrne.miyamoto@oregonstate.edu

\section{Matthew J. Konkler}

Faculty Research Assistant

E-mail: matthew.konkler@oregonstate.edu

\section{Scott Leavengood $\dagger$}

Associate Professor

Department of Wood Science and Engineering

Oregon State University

Corvallis, OR 97331

E-mail: scott.leavengood@ oregonstate.edu

\author{
Jeffrey J. Morrell $\dagger$ \\ Director \\ National Centre for Timber Durability and Design Life \\ University of the Sunshine Coast \\ Brisbane, Australia \\ E-mail: jmorrell@usc.edu.au \\ Arijit Sinha*† \\ Associate Professor \\ Department of Wood Science and Engineering \\ Oregon State University \\ Corvallis, OR 97331 \\ E-mail: arijit.sinha@oregonstate.edu
}

(Received October 2018)

\begin{abstract}
The relationship between extractives content and resistance to fungal attack was examined in heartwood samples of western juniper (Juniperus occidentalis) collected from across the growing range. Mass losses of juniper samples exposed to Trametes versicolor in laboratory decay tests were generally low and indicated that this species would be classified as highly durable, whereas mass losses for samples exposed to Gloeophyllum trabeum were higher and suggested that juniper heartwood was slightly less resistant to this fungus. Cedrol was the most common extractive in samples from four of five sites, whereas widdrol was most common in heartwood from the fifth site. The differences suggest the need for further studies to examine the possible roles of widdrol in decay resistance of this species. Extractives levels were generally poorly correlated with decay resistance, but there were substantial differences in extractives content between samples from different geographic areas. The results suggest the need for further evaluation of a wider range of samples to better determine the relationship between extractives and decay resistance.
\end{abstract}

Keywords: Juniperus occidentalis, heartwood, decay resistance, Gloeophyllum trabeum, Trametes versicolor, extractives.

\footnotetext{
* Corresponding author

$\dagger$ SWST member
} 


\section{INTRODUCTION}

Western juniper (Juniperus occidentalis) is native to drier, high-elevation areas in California, Oregon, Washington, Idaho, and Nevada (Miller et al 2005). Mature trees reach 4-28 $\mathrm{m}$ in height and measure $400-600 \mathrm{~mm}$ in diameter (source), but the bole has a very sharp taper that markedly reduces lumber recovery (Miller et al 2005). Juniper is sensitive to fires, but extreme fire suppression over the past five decades has allowed this species to expand into areas formerly occupied by native grasslands. Over the past decade, there has been a 7-fold increase in the area occupied by western juniper in eastern Oregon (Gedney et al 1999). Although western juniper is native, it has acted similarly to an invasive species, reducing the quality of animal habitat and choking out native grasses. Landowners have been encouraged to remove juniper to rehabilitate natural habitat and restore ecosystem balance.

One problem with encouraging western juniper harvests is a lack of markets for the resulting stems. This makes it uneconomical to cut and remove the stems. Western juniper has been evaluated for use in pencil stock, essential oils, and hardboard but is mainly used for fuel and fence posts. Juniper was also recently incorporated into the National Design Specifications, creating additional potential markets for the products (AWC 2018).

Western juniper heartwood is considered highly decay resistant and is allowed in selected local building codes for use in place of treated wood (Morrell et al 1999). The durability of western juniper has been attributed to the presence of terpene cedrol and high lignin levels (Kurth and Ross 1954; Highley 1995). Most decay resistance studies examine material from only a limited portion of the growing range of a species. Natural durability is known to vary widely between trees of the same species and also within individual trees (Scheffer and Cowling 1966; Zabel and Morrell 1992; Taylor et al 2002), but there are few data examining the decay resistance of a species across its growing range. The objective of this study was to examine decay resistance of materials collected from five widely separated growing areas of western juniper.

\section{MATERIALS AND METHODS}

\section{Material Preparation}

Western juniper cubes $(19 \mathrm{~mm} \times 19 \mathrm{~mm} \times$ $19 \mathrm{~mm}$ ) were cut from wood obtained from sites located in Idaho, Oregon (three sites), and California as described elsewhere (Miyamoto et al 2018). The materials were received as either whole boles or as precut timbers, making it impossible to reliably identify the stem location of materials from all sources. A total of 120 blocks were cut from each geographic source (total of 480 blocks). The blocks were oven-dried $\left(103^{\circ} \mathrm{C}\right)$ and weighed (to the nearest $0.001 \mathrm{~g}$ ) before being soaked with water for $30 \mathrm{~min}$ and subjected to 2.5 Mrad of ionizing radiation from a cobalt 60 source.

\section{Laboratory Decay Test}

The decay tests followed procedures described in American Wood Protection Association Standard E10 (AWPA 2016).

Decay chambers were prepared by half-filling 454-mL glass bottles with moist forest loam that had a water holding capacity of $49.5 \%$ and placing a western hemlock feeder strip on the soil surface. The bottles were then loosely capped and autoclaved for $45 \mathrm{~min}$ at $121^{\circ} \mathrm{C}$. After cooling, the bottles were inoculated with $3 \mathrm{~mm}$ diameter malt agar disks cut from the actively growing edges of cultures of the test fungi. The fungi evaluated in these procedures were a brown-rot, Gloeophyllum trabeum (Pers.ex Fr.) Murr. (Isolate \# Madison 617) (Fries), and a white-rot, Trametes versicolor (L. ex Fr.) Pilat (Isolate \# $\mathrm{R}$-105). The agar plugs were placed on the edges of the wood feeder strips; then the jars were loosely capped to allow air exchange and incubated until the feeder strip was thoroughly covered with fungal mycelium. The sterile test blocks were then placed on the surfaces of the feeder strips, and the bottles were loosely capped and incubated at $28^{\circ} \mathrm{C}$ for $16 \mathrm{wk}$. Although 
AWPA Standard E10 recommends 24 wk of incubation when exposing coniferous woods to white-rot fungi, we have found that a 16-wk exposure is sufficient to discern durability differences, if present, with $T$. versicolor. Blocks from each treatment group were also established in chambers without a test fungus to establish procedural mass losses with each material. Southern pine sapwood (Pinus spp.) was similarly prepared and exposed to the same decay fungi to serve as a decay-susceptible control. At the end of the incubation period, the blocks were removed, scraped clean of adhering mycelium, and weighed to determine wet weight. The blocks were then oven-dried $\left(103^{\circ} \mathrm{C}\right)$ and weighed. The difference between initial and final oven-dry weight was used as a measure of the decay resistance.

\section{Extractives Content}

Three cubes were chosen at random from each location and ground to pass a 20-mesh screen. The ground wood was then placed into a $50^{\circ} \mathrm{C}$ oven and weighed before Soxhlet extraction using hexane followed by methanol. Hexane was used to extract nonpolar compounds, whereas methanol extracted the more polar compounds. Five grams of ground juniper was placed into a cellulose thimble with a wire mesh placed over the sample. The thimble was placed in the Soxhlet with $300 \mathrm{~mL}$ of hexane. Extraction was performed for $6 \mathrm{~h}$; then the hexane was decanted. Hexane volume was reduced to $\sim 5 \mathrm{~mL}$ on a rotary evaporator; then a subsample was placed into a $1.8-\mathrm{mL}$ vial with a membrane cap and stored at $5^{\circ} \mathrm{C}$ until analyzed.

The hexane-extracted wood was air-dried and then subjected to Soxhlet extraction for $6 \mathrm{~h}$ using $300 \mathrm{~mL}$ of methanol. Methanol volume was similarly reduced to $\sim 5 \mathrm{~mL}$ by rotary evaporation and an $800 \mu \mathrm{L}$ sample was placed into a $1.8-\mathrm{mL}$ vial containing $800 \mu \mathrm{L}$ of a 2:1 acetonitrile and dichloromethane solution. Sodium sulfate was added to remove any water from the extract before analysis.

The residual sawdust was then oven-dried $\left(50^{\circ} \mathrm{C}\right)$ and weighed. The difference between initial and final oven-dry was used to calculate total extractives content. Extractions were performed in triplicate for material from each geographic source.

\section{GC-MS Analysis}

The samples were analyzed using a Shimadzu QP2010S GC-MS (Columbia, MD) operated in scan mode with an RXI-5ms column $(0.25 \mathrm{~mm}$ inner diameter by $30 \mathrm{~m}$ long) at a flow rate of $1.2 \mathrm{~mL} / \mathrm{min}$, a $\mathrm{m} / \mathrm{z}$ range of $45-900$, and a splitless injection port. One microliter of sample was injected and analysis was performed with the following $\mathrm{GC}$ conditions: temperature was held for $80^{\circ} \mathrm{C}$ for $2 \mathrm{~min}$, ramped at $10^{\circ} \mathrm{C} / \mathrm{min}$ to $190^{\circ} \mathrm{C}$, then ramped at $15^{\circ} \mathrm{C} / \mathrm{min}$ until $200^{\circ} \mathrm{C}$, and held for $5 \mathrm{~min}$, before being ramped to $300^{\circ} \mathrm{C}$ at $10^{\circ} \mathrm{C} / \mathrm{min}$ and held for $14 \mathrm{~min}$ (total run time $40 \mathrm{~min}$ ). The ion source temperature was $260^{\circ} \mathrm{C}$, the interface temperature was $250^{\circ} \mathrm{C}$, and the injection temperature was $250^{\circ} \mathrm{C}$.

The extractives present in the resulting chromatograms were identified using the National Institute of Standards and Technology (NIST) Mass Spectral Library \#107 software incorporated into Adams Essential Oil Components by GC/MS Library (NIST, Gaithersburg, MD; FarHawk Inc., Fineview, NY). The lack of standards for the extractives only allowed us to compare extractives on a relative basis using a ratio calculated using the formula,

$$
\frac{\text { Extractive Peak Area }}{\text { Total Peak Area of Sample }} \times 100 \text {. }
$$

A multitude of compounds were detected in the extracts, and there was considerable variation in compounds found in different samples, but most compounds were present at extremely low levels. To examine differences in extractives between samples, the percentages of chromatogram peak area were examined and the six most common compounds were compared.

\section{Statistical Analysis of Decay Tests}

Mass loss data were analyzed using a Kruskal-Wallis test to determine whether there were differences between weight loss and wood source using RStudio (ver. R 3.2.2, Boston, MA) (Siegel and 
Castellan 1988). This test was used because the data were not normally distributed and there were unequal variances in the mass loss data.

\section{RESULTS AND DISCUSSION}

\section{Mass Losses}

Southern pine sapwood samples exposed to $T$. versicolor experienced average weight losses of $32 \%$, whereas those exposed to G. trabeum experienced average weight losses of $42.6 \%$ (Table 1 ). Although the T. versicolor weight losses were a bit below the $40 \%$ required in AWPA Standard E10, this fungus tends to be less aggressive on softwoods. The results still indicate that test conditions were suitable for aggressive fungal attack.

T. versicolor produced little mass loss in the juniper blocks over the 16-wk exposure. Average weight losses ranged from $0.30 \%$ in samples from Idaho to $1.72 \%$ in samples from Klamath (Table 1) (Fig 1). Weight losses in the nonfungal inoculated controls were similar to the $T$. versicolor inoculated samples, indicating that there was little to no attack on the inoculated samples. Juniper contains more lignin than other wood species and this, coupled with the presence of extractives such as cedrol, may have contributed to the decay resistance of this wood (Myers et al 1998; Tumen et al 2013). These results would classify western juniper from all five sources as highly decay resistant to this fungus according to the guidelines in ASTM Standard D2017 (ASTM 2001).

G. trabeum produced weight losses ranging from 1.5 to $11.0 \%$ over the 16 -wk decay test. Blocks cut from wood obtained from Burns, Klamath Falls, Prineville, and Idaho all experienced weight losses below $10 \%$ and would be classified as highly decay resistant. Samples from California experienced slightly higher weight losses (11\%) and would be classified as decay resistant. The mass losses from the Idaho source were higher than those from any of the Oregon sites and far more variable, suggesting that there was more variability in decay resistance in samples from this location. The results indicate that western juniper is less decay resistant against the brown-rot fungus and are supported by previous studies showing that cedrol, the main extractive in western juniper, is less effective against brown-rot fungi (Tumen et al 2013).

There also seemed to be substantial differences in mass loss among the test blocks as evidenced by increased standard deviation when blocks were exposed to $G$. trabeum. Heartwood decay resistance is a natural biological property and is known to vary with distance from the pith to the sapwood as well as from the butt to the tip of a growing tree (Scheffer and Cowling 1966; Zabel and Morrell 1992; Hillis 2002; Taylor et al 2002). The way in which these materials were supplied makes it difficult to determine whether the variability seen in some populations, for example, the California site, was due to stem position or regional differences in decay resistance within the species.

\section{Extractives Content}

The average extractive yield for all samples was $8.67 \%( \pm 2.54 \%)$ and ranged from 6.94 to

Table 1. Mass losses of western juniper heartwood samples from various geographic sources compared with those of southern pine sapwood as determined by exposure to decay fungi in an American Wood Protection Association E10 soil block test.

\begin{tabular}{|c|c|c|c|c|}
\hline \multirow[b]{2}{*}{ Wood species } & \multirow[b]{2}{*}{ Geographic source } & \multicolumn{3}{|c|}{ Wood weight loss $(\%)^{\mathrm{a}}$} \\
\hline & & Trametes versicolor & Gloeophyllum trabeum & No fungus \\
\hline \multirow[t]{5}{*}{ Western juniper } & Burns & $1.63(0.50)$ & $1.51(1.70)$ & $2.30(0.70)$ \\
\hline & Klamath & $1.72(1.50)$ & $2.85(1.80)$ & $0.96(1.10)$ \\
\hline & Prineville & $1.50(0.80)$ & $4.09(4.70)$ & $0.89(0.30)$ \\
\hline & California & $1.04(0.70)$ & $11.06(19.40)$ & $1.48(0.10)$ \\
\hline & Idaho & $0.30(0.90)$ & $7.95(8.30)$ & $1.49(0.30)$ \\
\hline Southern pine & - & $32.15(9.40)$ & $42.55(25.2)$ & $-0.32(0.20)$ \\
\hline
\end{tabular}

${ }^{a}$ Values for western juniper represent means of 40 samples/fungus from each geographic source, whereas values for southern pine represent means of six replicates/fungus. Values in parentheses represent one standard deviation. 


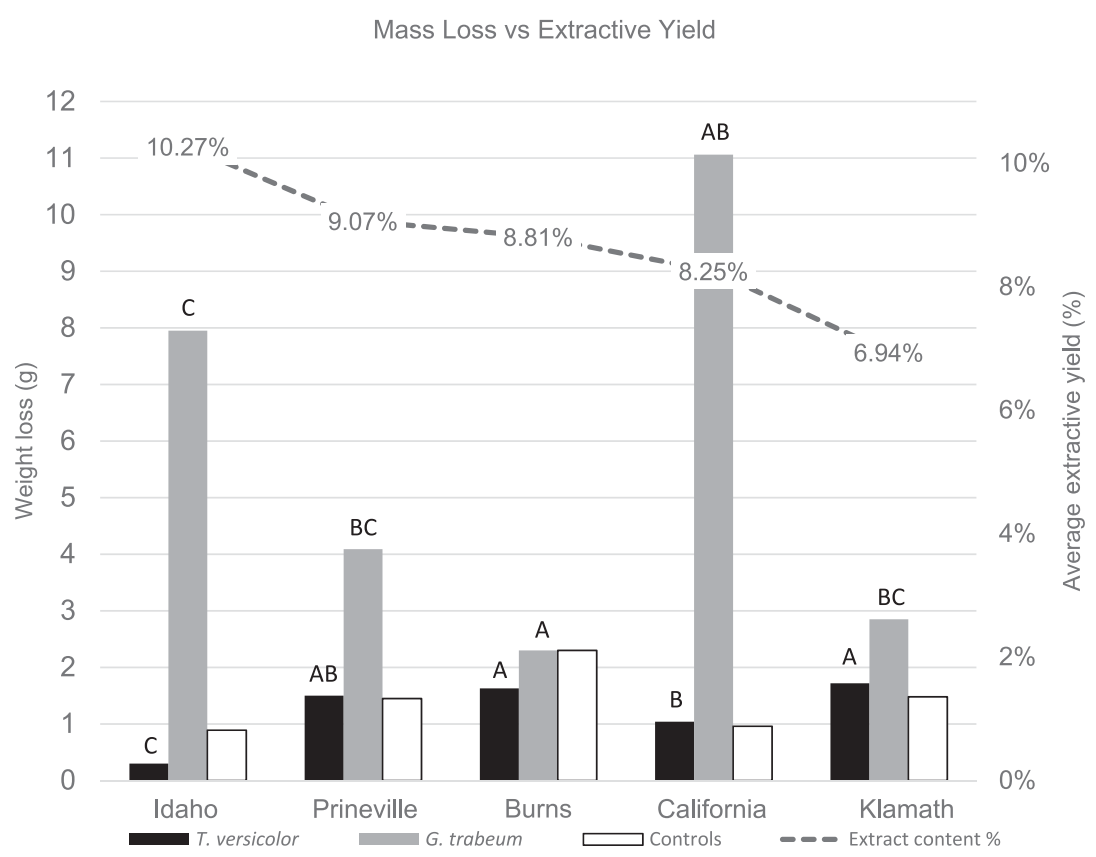

Figure 1. Relationship between extractives content of western juniper from various geographic sources and mass losses when heartwood is exposed to a decay fungus in an American Wood Protection Association E10 soil block test (bars with different letters differ statistically at $\alpha=0.05$ ).

10.27\%. Samples from Prineville had the lowest extractives content, whereas those from Idaho had the highest. It is unclear why the Idaho samples which had higher extractives levels experienced higher mass losses, although levels of extractives components could partially explain these differences. Cedrol, $\alpha$-cedrene, $\beta$-cedrene, thujopsene, widdrol, and alaskene were the six most common extractives found in extractives from all five locations (Fig 2). Because of the small sample size, a statistical analysis could not be performed, but a descriptive analysis was performed. Average percentage peak areas for the top six extractives for each location can be seen in Table 2 .

Extractive yields ranged from 4 to $12 \%$. The highest extractives levels were found in samples from the Idaho location, whereas the lowest extractive levels were found in samples from the Klamath location. Cedrol and $\alpha$-cedrene are sesquiterpenes found in cypresses, cedars, and junipers and were the most abundant compounds in extracts from most of the locations. Junipers typically contain high amounts of cedrol, thujopsene, and widdrol (Mun and Prewitt 2011; Tumen et al 2013). The former two extractives are most active against fungi. Western juniper extracts in the current study contained little thujopsene. These results were similar to those found by Tumen et al (2013). Mass losses after exposure to $G$. trabeum were poorly correlated with extractives levels.

Extractives content in samples from Klamath Falls differed from those found in extracts from the other sites, with $\alpha$-cedrene and widdrol having the highest peak areas, rather than cedrol. Cedrol levels were exceptionally low in the Klamath Falls samples, representing only $11.66 \%$ and $12.7 \%$ of the total peak area, compared with the other locations which averaged around 45\% of the peak area. Differences in extractives content could reflect genetic differences or variations in growing conditions at the various sites. However, these differences seemed to have no effect, because there was little mass loss with $T$. versicolor or G. trabeum (Fig 3). Extractives from Idaho and California samples contained the 


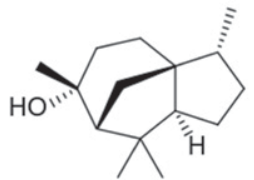

Cedrol $\left(\mathrm{C}_{15} \mathrm{H}_{26} \mathrm{O}\right)$<smiles>CC1=CC[C@]2(C)CCCC3(C)C[C@H]1[C@@]32C</smiles>

Thujopsene $\left(\mathrm{C}_{15} \mathrm{H}_{24}\right)$

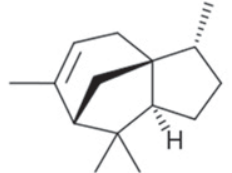

$\alpha$-Cedrene $\left(\mathrm{C}_{15} \mathrm{H}_{24}\right)$

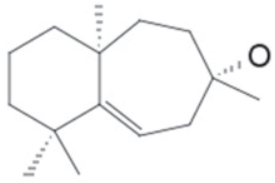

Widdrol $\left(\mathrm{C}_{15} \mathrm{H}_{26} \mathrm{O}\right)$

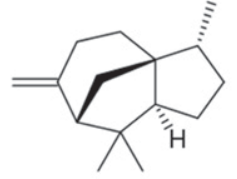

$\beta$-Cedrene $\left(\mathrm{C}_{15} \mathrm{H}_{24}\right)$

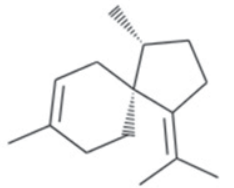

Alaskene $\left(\mathrm{C}_{15} \mathrm{H}_{24}\right)$

Figure 2. Structures of the six most common compounds detected in hexane and methanol extracts from western juniper heartwood (Adams Essential Oil Components by GC/MS, Fineview, NY).

most cedrol, but samples from these two locations experienced the most mass loss by G. trabeum. Extracts from these two locations also had little to no trace of widdrol, whereas the locations with higher amounts of widdrol, including those from Klamath and Burns, were more resistant to $G$. trabeum (Fig 3). The wide growing range of western juniper coupled with its sometimes isolated, dispersed habitats increases the likelihood for segregation of breeding populations that might select for specific growth characteristics including extractives content. However, the limited studies performed on this species make it difficult to determine a specific cause for the differences. The limited number of samples examined made it difficult to make definitive conclusions, but the results suggest the need for further assessments of differences in extractives levels across the growing region.

\section{CONCLUSIONS}

Western juniper could be considered as a prominent naturally durable wood substitute for preservativetreated wood, but special care would be needed to include only heartwood. There seemed to be some differences in locations based on mass loss and extractives content, with little difference in extractive yield. The most abundant extractive was cedrol, which has been reported to account for the excellent durability of western juniper. The Klamath locations showed lower levels of cedrol with higher levels of other common compounds found in juniper. The results suggest that more samples need to be examined to better understand the relationships

Table 2. Relative frequencies of the 10 most common compounds detected in extracts of western juniper heartwood from five geographic locations.

\begin{tabular}{|c|c|c|c|c|c|c|c|c|c|c|}
\hline \multirow[b]{3}{*}{ Compound } & \multicolumn{10}{|c|}{ Relative abundance ( $\%$ of total peak area) } \\
\hline & \multicolumn{2}{|c|}{ Idaho } & \multicolumn{2}{|c|}{ California } & \multicolumn{2}{|c|}{ Prineville } & \multicolumn{2}{|c|}{ Klamath } & \multicolumn{2}{|c|}{ Burns } \\
\hline & Hexane & Methanol & Hexane & Methanol & Hexane & Methanol & Hexane & Methanol & Hexane & Methanol \\
\hline Cedrol & 51.65 & 59.53 & 64.06 & 51.07 & 33.80 & 45.07 & 11.66 & 12.70 & 39.98 & 37.60 \\
\hline$\alpha$-Cedrene & 8.34 & 12.71 & 15.53 & 21.25 & 13.69 & 23.04 & 14.95 & 17.36 & 9.98 & 19.01 \\
\hline$\beta$-Cedrene & 0.00 & 2.08 & 2.02 & 3.20 & 1.22 & 3.23 & 0.43 & 1.85 & 0.69 & 4.14 \\
\hline Thujopsene & 0.67 & 1.01 & 3.86 & 1.45 & 3.06 & 3.55 & 1.69 & 2.40 & 1.53 & 2.81 \\
\hline Widdrol & 0.00 & 0.00 & 0.00 & 0.00 & 4.60 & 0.00 & 4.43 & 21.31 & 10.78 & 1.01 \\
\hline Alaskene & 2.25 & 2.85 & 0.00 & 1.33 & 0.00 & 1.40 & 0.00 & 2.13 & 6.84 & 0.85 \\
\hline
\end{tabular}

Values represent the average percentage peak area of a given compound in nine chromatograms from each geographic site. 

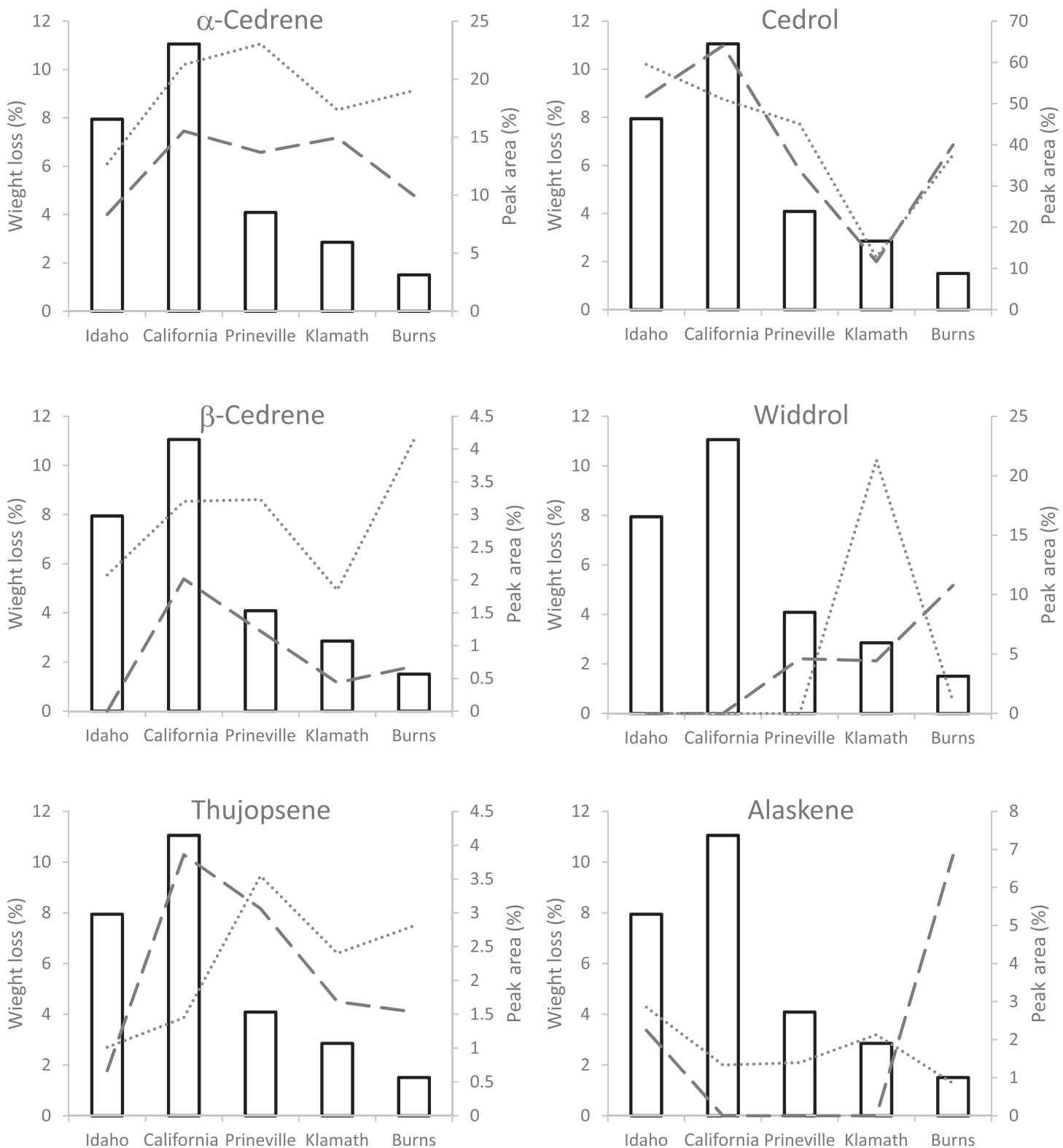

Figure 3. Average extractive contents for hexane (dashed line) and methanol (dotted line) extracts from western juniper heartwood samples from five different geographic sources compared with mass loss caused by exposure to Gloeophyllum trabeum in an American Wood Protection Association soil block test (black hollow bars).

between extractives content and decay resistance of a given wood species across its growing range.

\section{ACKNOWLEDGMENTS}

The authors would like to acknowledge Sustainable Northwest, Business Oregon, and Oregon
DOT for providing financial support for this work.

\section{REFERENCES}

American Society for Testing Materials (ASTM) (2001) Standard D-2017. Standard method of accelerated laboratory 
test of natural decay resistance of woods (withdrawn 2005). ASTM Annual Book of Standards, Volume 4.10 Wood. ASTM, West Conshohocken, PA. pp. 322-326.

American Wood Council (AWC) (2018) National design specification ${ }^{\circledR}$ for wood construction. AWC, Leesburg, VA.

American Wood Protection Association (AWPA) (2016) Standard E10 Standard method of testing wood preservatives by laboratory soil-block cultures. AWPA Book of Standards. AWPA, Birmingham, AL. pp. 448-458.

Gedney DR, Azuma DL, Bolsinger CL, McKay N (1999) Western juniper in eastern Oregon. USDA Forest Service Pacific Northwest Research Station General Technical Report PNW-GTR-464. 64 pp.

Highley TL (1995) Comparative durability of untreated wood in use above ground. Int Biodeterior Biodegrad 35: 409-419.

Hillis WE (2002) Heartwood and tree exudates. SpringerVerlag, Berlin, Germany. 268 pp.

Kurth EF, Ross JD (1954) Volatile oil from western juniper. Report No. C-3, Oregon Forest Products. Oregon State University, Corvallis, OR.

Miller RF, Bates JD, Svejcar TJ, Pierson FB, Eddleman LE (2005) Biology, ecology, and management of western juniper (Juniperus occidentalis). Oregon State University Agricultural Experiment Station Technical Bulletin 152. $82 \mathrm{pp}$.

Miyamoto BT, Sinha A, Leavengood S, Morrell JJ, DeVisser D, Kruse D (2018) Mechanical property assessment for establishing design values of western juniper. Wood Fiber Sci 50:167-179.

Morrell JJ, Miller DJ, Schneider PF (1999) Service life of treated and untreated fence posts: 1996 post farm report. Research Contribution 26. Forest Research Laboratory, Oregon State University, Corvallis, OR. 24 pp.

Mun SP, Prewitt L (2011) Antifungal activity of organic extracts from Juniperus virginiana heartwood against wood decay fungi. For Prod J 61(6):443-449.

Myers CG, Weidenhoeft WM, Davis WM (1998) Basic fiber and chemical properties of western juniper, Prepared by the U.S. Forest Products Laboratory, Madison, WI. Unpublished report. 3 .

Scheffer TC, Cowling EB (1966) Natural resistance of wood to deterioration. Ann Rev Phytopathol 4:147-170.

Siegel S, Castellan NJ (1988) Nonparametric statistics for the behavioral sciences, 2nd edition. Mcgraw-Hill Book Company, New York, NY and England, UK.

Taylor AM, Gartner BL, Morrell JJ (2002) Heartwood formation and natural durability - a review. Wood Fiber Sci 34(4):587-611.

Tumen I, Eller FJ, Clausen CA, Teel JA (2013) Antifungal activity of heartwood extracts from three Juniperus species. BioResources 8(1):12-20.

Zabel RA, Morrell JJ (1992) Wood microbiology: Decay and its prevention. Academic Press Inc., San Diego, CA. 